\title{
Regulation of mammary parenchymal growth by the fat pad in prepubertal dairy heifers: role of inflammation-related proteins
}

\author{
Stephanie R Thorn, Stig Purup ${ }^{1}$, Mogens Vestergaard ${ }^{1}$, Kris Sejrsen ${ }^{1}$, Matthew J Meyer, \\ Micheal E Van Amburgh and Yves R Boisclair \\ Department of Animal Science, Cornell University, 259 Morrison Hall, Ithaca, New York 14853, USA \\ ${ }^{1}$ Department of Animal Health, Welfare and Nutrition, Faculty of Agricultural Sciences, University of Aarhus, DK-8830 Tjele, Denmark \\ (Correspondence should be addressed to Y Boisclair; Email: yrb1@cornell.edu)
}

\begin{abstract}
In prepubertal heifers, the mammary parenchyma consists of epithelial and myoepithelial cells growing within a mammary fat pad (MFP). The MFP produces IGF-I that stimulates epithelial cell proliferation. In other species, adipose tissue expansion induces inflammation-related proteins (IRP), such as tumor necrosis factor $\alpha(\mathrm{TNF} \alpha)$, interleukin (IL)-6, IL-1 $\beta$ transforming growth factor $\beta$, monocyte chemoattractant protein 1 (MCP-1), and plasminogen activator inhibitor-1 (PAI-1). The MFP production of IRP may influence mammary development because they impair not only insulin but also IGF-I actions. Moreover, the MFP expansion seen with development and increased nutrition coincides with reduced parenchymal growth. Our first objective was to identify IRP capable of altering proliferation of bovine mammary epithelial cells. TNF $\alpha$, but neither IL-6, IL-1 $\beta$ MCP-1 nor PAI-1, inhibited basal and
\end{abstract}

IGF-I-stimulated proliferation in MAC-T cells and primary cells isolated from heifers. Our second objective was to determine whether MFP expression of IRP changed in a manner consistent with inhibition of parenchymal growth. MFP expression was measured from 100 to $350 \mathrm{~kg}$ body weight (experiment 1) or at $240 \mathrm{~kg}$ body weight (experiment 2) in dairy heifers offered restricted or high planes of nutrition. In experiment 1 , neither nutrition nor development altered MFP expression of TNF $\alpha$. Nutrition increased MCP-1 and PAI-1 but only before MFP expansion and after cessation of allometric parenchymal growth. In experiment 2 , nutrition increased TNF $\alpha$ and PAI-1, but not MCP-1. Thus, MFP expansion increases IRP production in cattle, but this is unlikely to contribute to reduced parenchymal growth observed with development or increased nutrition.

Journal of Endocrinology (2008) 196, 539-546

\section{Introduction}

In rodents and humans, increased adiposity induces adipose tissue production of the proinflammatory cytokines tumor necrosis factor $\alpha$ (TNF $\alpha$ ), interleukin (IL)-6, and IL-1 $\beta$ (Wellen \& Hotamisligil 2005, Tilg \& Moschen 2006). These cytokines interfere with insulin signaling in adipose tissue, liver, and muscle, leading to the development of whole-body insulin resistance (Wellen \& Hotamisligil 2005, Shoelson et al. 2006). All three cytokines also impair insulin-like growth factor-I (IGF-I)-stimulated proliferation of human mammary epithelial cells (Shen et al. 2002). Mechanistically, these inhibitory actions occur because inflammatory cytokines attenuate the activity and abundance of signaling elements shared by both insulin and IGF-I (e.g. insulin receptor substrate-proteins (IRS) proteins; Rui et al. 2002, Wellen \& Hotamisligil 2005).

Adipose tissue expansion also induces the production of other proteins associated with inflammation, including transforming growth factor $\beta$ (TGF $\beta 1$ ), monocyte chemoattractant protein 1 (MCP-1), and plasminogen activator inhibitor-1 (PAI-1; Tilg \& Moschen 2006). TGF $\beta 1$ reduces serum-stimulated proliferation of bovine mammary epithelial cells (Woodward et al. 1995, Purup et al. 2000a). MCP-1 is a chemoattractant molecule that recruits monocytes to adipose tissue (Chen et al. 2005, Kanda et al. 2006). PAI-1 not only inhibits the activity of urokinase and tissue plasminogen activator proteins ( $\mathrm{uPA}$ and $\mathrm{tPA}$ ), which generate plasmin, but also modulates the biological activities of proteins such as vitronectin and IGF-I-binding protein 5 (Stefansson \& Lawrence 1996, Maile et al. 2006, Sorrell et al. 2006). MCP-1 and PAI-1 have been shown to attenuate insulin signaling and cell growth in non-bovine systems (Lopez-Alemany et al. 2003, Kanda et al. 2006, Kortlever et al. 2006, Sell et al. 2006).

The ability of adipose tissue to produce inflammation-related proteins (IRP) could be relevant to the growth of the mammary parenchymal compartment of prepubertal dairy heifers. At this stage of development, the parenchyma consists of epithelial and myoepithelial cells growing as multi-layered duct-like structures within the mammary fat pad (MFP). This arrangement maximizes epithelial cell exposure to essential mitogens produced by the MFP, such as IGF-I (Walden et al. 1998, Kleinberg et al. 2000, Meyer et al. 2006a, Connor et al. 2007). In theory, it would also facilitate growth inhibition if MFP expansion triggered the synthesis of IRP. This possibility is 
suggested by situations where indices of parenchymal and MFP growth are inversely related. Specifically, expansion of the MFP in rapidly growing dairy heifers is associated with decreased parenchymal growth when assessed at a similar body weight (Sejrsen et al. 1982, Capuco et al. 1995). Moreover, cessation of allometric parenchymal growth occurs near $300 \mathrm{~kg}$ body weight when the MFP has expanded significantly (Meyer et al. 2006b).

These observations raise the possibility that MFP expansion induces the synthesis of IRP, which then impair mammary epithelial cell growth. Our first objective was to identify which IRP, previously shown to be produced by human or rodent adipose tissue, could inhibit proliferation of bovine mammary epithelial cells in vitro. Our second objective was to verify physiological relevance for the inhibitors identified in vitro. We did so by determining whether MFP expression of these factors was inversely related with indices of parenchymal growth in prepubertal dairy heifers.

\section{Materials and Methods}

\section{$\left[{ }^{3} \mathrm{H}\right]$ thymidine incorporation in bovine mammary epithelial cells}

The MAC-T bovine mammary epithelial cell line was established from primary bovine mammary alveolar cells by immortalization with the SV-40 large T antigen (Huynh et al. 1991). MAC-T cells were routinely grown at $37^{\circ} \mathrm{C}$ with $5 \%$ $\mathrm{CO}_{2}$ in basal Dulbecco's modified Eagle's medium (DMEM with $4.5 \mathrm{~g} / 1$ glucose containing $20 \mathrm{U} / \mathrm{ml}$ penicillin, $2 \cdot 4 \mathrm{nM}$ glutamine) supplemented with $10 \%$ fetal calf serum and $5 \mu \mathrm{g} /$ $\mathrm{ml}$ insulin (Thorn et al. 2006). For proliferation assays, MAC-T cells were plated at $1 \times 10^{4}$ cells $/ \mathrm{cm}^{2}$ into 48 -well plates and cultured for $48 \mathrm{~h}$. Cells were washed twice with PBS and incubated in basal DMEM for $24 \mathrm{~h}$. After $24 \mathrm{~h}$, the media was changed to basal DMEM supplemented with [methyl- ${ }^{3} \mathrm{H}$ ] thymidine ( $1 \mu \mathrm{Ci}$ /well; MP Biomedicals, Irvine, CA, USA) and hormones for $18 \mathrm{~h}$ as indicated in figure legends.

Primary mammary epithelial cell (pMEC) organoids were obtained from two independent isolations by digestion of the parenchymal mammary compartment of prepubertal Friesian heifers, as described previously (Purup et al. 2001). Frozen stocks of pMEC were thawed as needed in basal medium 199 (M199 containing $2 \cdot 6 \mathrm{~g} / 1 \mathrm{BSA}, 5 \mathrm{mg} / 1$ transferrin, $1 \mathrm{mg} / 1$ reduced glutathione, $1 \mathrm{mg} / 1$ soybean trypsin inhibitor, $1 \mu \mathrm{g} / 1$ selenium, $0 \cdot 2 \%$ penicillin, and streptomycin antibiotic solution) and kept at $37^{\circ} \mathrm{C}$ with $5 \% \mathrm{CO}_{2}$. For cell proliferation assays, the two independent cell isolates were mixed and seeded in basal M199 supplemented with $10 \mu \mathrm{g} / 1$ insulin (Sigma) into threedimensional gels, as described previously (Weber et al. 1999). After $24 \mathrm{~h}$, cells were incubated for 4 days with basal M199 supplemented with insulin and indicated hormones (see figure legends). Media were changed every 2 days and [methyl- ${ }^{3} \mathrm{H}$ ] thymidine was added for the last $24 \mathrm{~h}$ of the culture period.

For both cell systems, all treatments were performed in triplicate. Thymidine incorporation was measured, as previously reported (Thorn et al. 2006). Human recombinant proteins tested were TNF $\alpha$ (PeproTech Ltd, Rocky Hill, NJ, USA), IL-6 (PeproTech), IL-1 $\beta$ (PeproTech), MCP-1 (PeproTech), the stable and constitutively active form of PAI-1 described by Czekay et al. (2003) (Calbiochem, San Diego, CA, USA), and IGF-I (National Institute of Diabetes \& Digestive \& Kidney Diseases, Bethesda, MA, USA for MAC-T; Austral Biologicals, San Ramon, CA, USA for pMEC).

\section{Prepubertal heifer experiments}

Mammary adipose tissue was obtained from two experiments performed in prepubertal dairy heifers. All experimental procedures were conducted with the approval of the local Institutional Animal Care and Use Committee (Cornell University or Danish Animal Experimentation Inspectorate). In the first experiment performed at Cornell University, Holstein dairy heifers were randomly assigned to a restricted (R) or high (H) plane of nutrition beginning at 10 days of age to attain an average daily gain (ADG) of 650 or $950 \mathrm{~g} /$ day respectively, as previously described (Meyer et al. 2006c). Heifers in each treatment group were killed at 100, 150, 200, 250, 300, and $350 \mathrm{~kg}$ body weight ( $n=6$ per group). In the second experiment performed at the Danish Institute of Agricultural Sciences, Holstein-Friesian dairy heifers were randomly allocated at 42 days of age to a $\mathrm{R}$ or $\mathrm{H}$ plane of nutrition ( $n=12$ per treatment) to attain an ADG of 700 or $1200 \mathrm{~g} /$ day respectively, as described previously (Thorn et al. 2006). Heifers in both treatments were killed at $240 \mathrm{~kg}$ body weight. In both experiments, mammary gland weights were recorded and MFP samples were collected and snap frozen in liquid nitrogen.

\section{Measurement of cytokine gene expression}

Representative samples (200 mg) of MFP tissue were homogenized with $1 \mathrm{ml}$ Qiazol (Qiagen). Total RNA was isolated and purified using RNeasy Mini columns and on-column RNasefree DNase treatment (Qiagen) following the manufacturer's protocol. Quantity and integrity of RNA was determined using the RNA Nano Lab Chip Kit (Agilent; Palo Alto, CA, USA). Reverse transcription reactions were performed with $2 \mu \mathrm{g}$ RNA, $500 \mathrm{ng}$ random primers (Invitrogen), and ImPromII reverse transcriptase (Promega) in a $20 \mu \mathrm{l}$ volume.

Gene expression was measured by real-time PCR. TNF $\alpha$ transcripts were detected with a Taqman probe assay, whereas TGF $\beta 1$, MCP-1, PAI-1, and 18S transcripts were detected with a SYBR green assay (Table 1). A previously validated assay was used for leptin (Thorn et al. 2006). Reactions were performed in duplicate in a $25 \mu$ volume using Perfect Real Time $2 \times$ Premix with supplied ROX dye (Takara; Madison, WI, USA) for leptin, $2 \times$ Universal Mix (Applied Biosystems Inc., Foster City, CA, USA) for TNF $\alpha$, and Power SYBR Mix (Applied Biosystems Inc.) for other assays. Reactions contained $500 \mathrm{nM}$ of each primer, $100 \mathrm{nM}$ probe (for leptin and TNF $\alpha$ assays), and diluted cDNA (20 ng reversetranscribed RNA, except $2 \mathrm{ng}$ for 18S). The average S.D. for sample $C_{\mathrm{T}}$ was $0 \cdot 10$. To analyze the data, a relative standard 
Table 1 Real-time PCR primer and probe sequences

Sequence $^{\mathrm{a}}$

\begin{tabular}{|c|c|}
\hline anscript & \\
\hline $\mathrm{TNF} \alpha$ & F': GGTCCTСТTCTCAAGССТCAAG \\
\hline & R': AGCTGCCCCGGAGAGTTG \\
\hline & Probe: FAM-CGGTAGCCCACGTTGTAGCCGACA-TAMRA \\
\hline TGF $\beta 1$ & F': GGCССТGСССТTАСАТСТG \\
\hline & $\mathrm{R}^{\prime}$ : CCGGGTTGTGCTGGTTGTAC \\
\hline MCP-1 & $\mathrm{F}^{\prime}:$ CACCAGCAGCAAGTGTCCTA \\
\hline & R': GCTTGGGGTCTGCACATAAC \\
\hline PAI-1 & $F^{\prime}$ : AGCTGACCACAGGAGGAGAA \\
\hline & R': TCCTTGTACAGTCGGTGGAA \\
\hline $18 \mathrm{~S}$ & 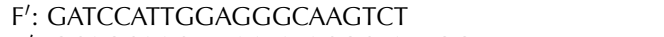 \\
\hline & R': GCAGCAACTTTAATATACGCTATTGG \\
\hline
\end{tabular}

${ }^{\mathrm{a}}$ For each transcript, the sequence of the forward primer $\left(\mathrm{F}^{\prime}\right)$, reverse primer $\left(\mathrm{R}^{\prime}\right)$, and probe are given in the $5^{\prime}$ to $3^{\prime}$ direction. FAM, carboxyfluorescein; TAMRA, carboxytetramethylrhodamine.

curve was generated for each transcript using pooled cDNA prepared from prepubertal mammary parenchyma and MFP. The relative standard curve consisted of six serial twofold dilutions of the pooled cDNA. Amplification was linear and efficient across the range of standards for each assay (efficiency for all assays was $>0 \cdot 9$, based on efficiency $=10^{(-1 / \text { slope })}-1$, where slope is obtained from regression of $C_{\mathrm{T}}$ versus $\log$ input). Unknown sample expression was then determined from the standard curve, adjusted for 18S, and expressed as a fold difference as indicated in the figure legends.

\section{Statistical analysis}

Analyses were performed using SAS statistical software (SAS Institute, Cary, NC, USA). When testing a single dose, thymidine incorporation data from the MAC-T and pMEC experiments were analyzed separately with the fixed effects of IRP (TNF $\alpha$, IL-6, IL-1 $\beta$, MCP-1, or PAI-1), IGF-I, their interaction (INT), and experiment (block). For the doseresponse experiments, thymidine incorporation data in basal and IGF-I-stimulated conditions were analyzed separately from the MAC-T and pMEC experiments. The model included the fixed effect of treatment dose and experiment (block). Treatment dose differences were detected using multiple comparison tests with a Tukey adjustment. Gene expression data were analyzed with a mixed model accounting for nutrition, body weight at slaughter, and their INT in the first experiment, or only the effect of nutrition in the second experiment. Statistical significance was declared at $P<0 \cdot 05$.

\section{Results}

Effect of IRP on the proliferation of bovine mammary epithelial cells

The effects of IRP were first evaluated in the transformed mammary epithelial cell line, MAC-T, using thymidine incorporation as an index of proliferation. These cells are responsive to IGF-I as evidenced by a two to threefold increase in proliferation $(P<0 \cdot 001$, Fig. 1$)$. Treatment of the MAC-T cells with $10 \mathrm{ng} / \mathrm{ml} \mathrm{TNF} \alpha$-reduced proliferation by 50\% under basal growth conditions and $70 \%$ in the presence of IGF-I (INT $P<0 \cdot 001$, Fig. 1). In contrast, the proinflammatory cytokines IL-6 or IL-1 $\beta$, the chemoattractant MCP-1, and the inhibitor of plasminogen activation PAI-1 did not alter thymidine incorporation under basal or IGF-I-stimulated growth conditions even if used at high concentrations (50-100 $\mathrm{ng} / \mathrm{ml}$, Fig. 1).

We also determined whether these IRP had similar effects on primary mammary epithelial cells isolated from prepubertal dairy heifers (pMEC cells). Proliferation in these cells is also IGF-I dependent, with an almost twofold increase in thymidine incorporation when incubated with IGF-I at the concentration of $10 \mathrm{ng} / \mathrm{ml}(P<0 \cdot 001$, Fig. 2). As seen with the MAC-T cells,

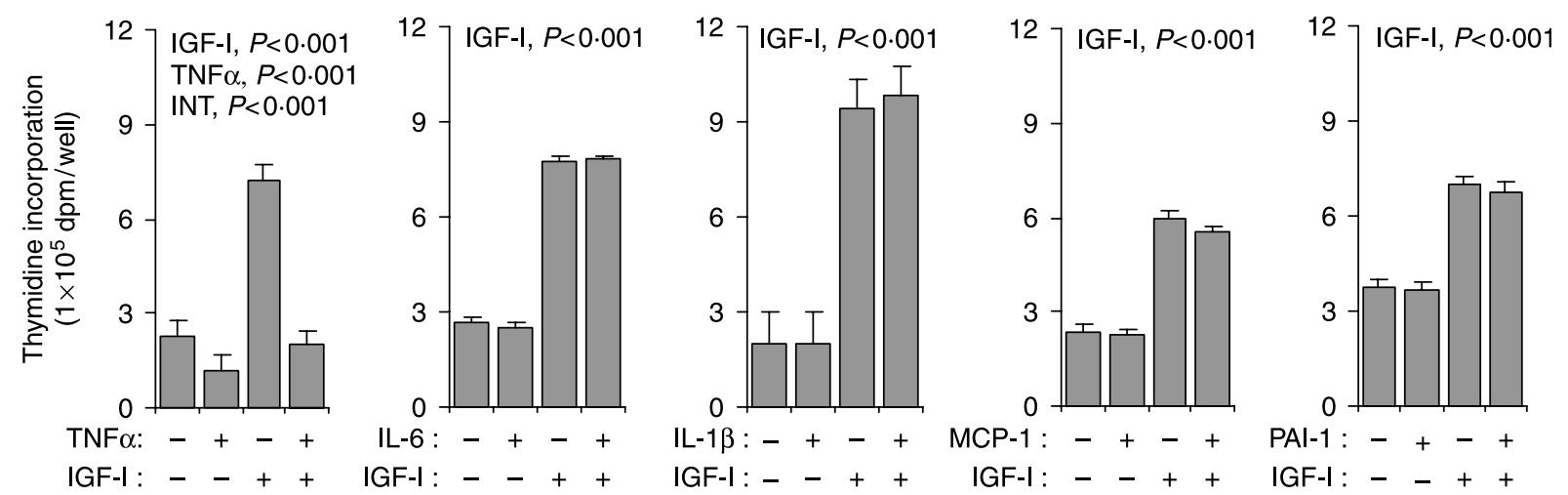

Figure 1 Effect of inflammation-related proteins on $\left[{ }^{3} \mathrm{H}\right]$ thymidine incorporation in MAC-T cells. MAC-T were plated and grown in complete media for $48 \mathrm{~h}$ and then washed and incubated in basal media for $24 \mathrm{~h}$. Cells were incubated under the same conditions in the absence or presence of TNF $\alpha(10 \mathrm{ng} / \mathrm{ml}), \mathrm{IL}-6(50 \mathrm{ng} / \mathrm{ml}), \mathrm{IL}-1 \beta(100 \mathrm{ng} / \mathrm{ml}), \mathrm{MCP}-1(100 \mathrm{ng} / \mathrm{ml})$, PAI-1 $(100 \mathrm{ng} / \mathrm{ml})$, and IGF-I $(10 \mathrm{ng} / \mathrm{ml})$. Hormone treatments and $\left[{ }^{3} \mathrm{H}\right]$ thymidine were added for $18 \mathrm{~h}$. Mean \pm S.E.M. is shown for each treatment. The effects of IGF-I, inflammation-related protein (TNF $\alpha$, IL-6, IL-1 $\beta, \mathrm{MCP}-1$, or PAI-1), and their interaction (INT) are reported when significant $(P<0 \cdot 05)$. Data are representative of two or three experiments. 


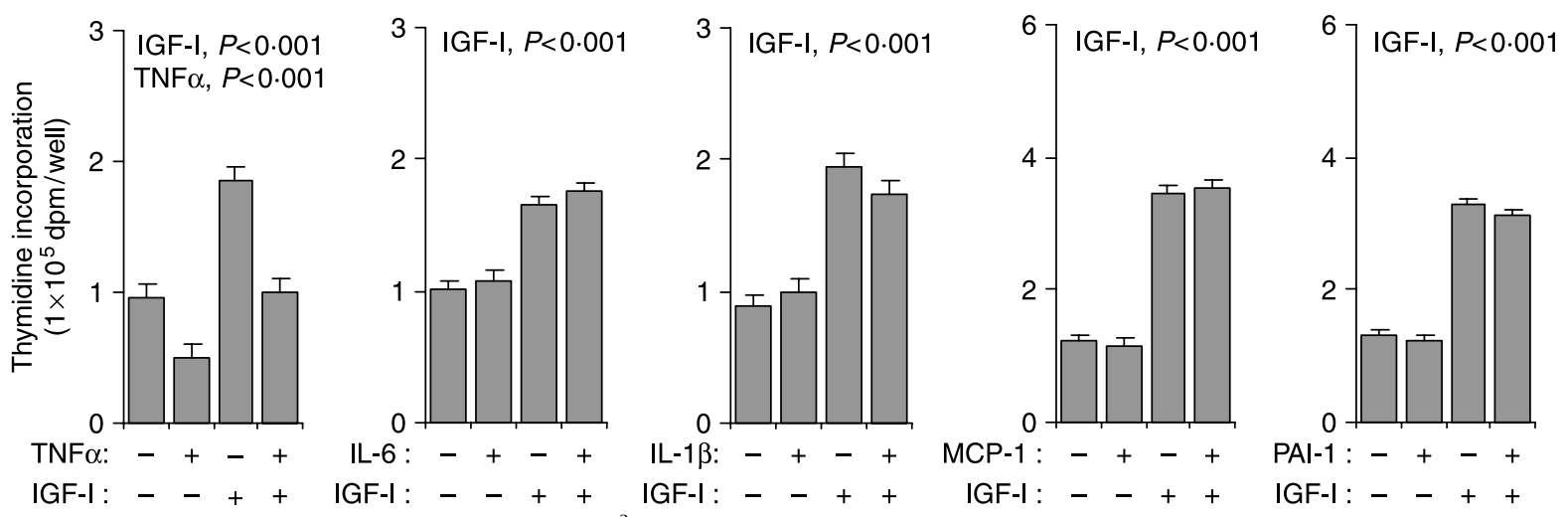

Figure 2 Effect of inflammation-related proteins on $\left[{ }^{3} \mathrm{H}\right]$ thymidine incorporation in pMEC cells. pMEC were plated and incubated in basal media supplemented with insulin for $24 \mathrm{~h}$. Cells were incubated under the same conditions in the absence or presence of TNF $\alpha$, $(10 \mathrm{ng} / \mathrm{ml}), \mathrm{IL}-6(100 \mathrm{ng} / \mathrm{ml}), \mathrm{IL}-1 \beta,(100 \mathrm{ng} / \mathrm{ml})$, MCP-1 $(100 \mathrm{ng} / \mathrm{ml})$, PAl-1 $(100 \mathrm{ng} / \mathrm{ml})$, and IGF-I $(10 \mathrm{ng} / \mathrm{ml})$. Cells were incubated with hormone treatments for 4 days with a media change every 2 days, and $\left[{ }^{3} \mathrm{H}\right]$ thymidine was added for the last $24 \mathrm{~h}$ of the culture period. Mean \pm S.E.M. is shown for each treatment. The effects of IGF-I and inflammation-related protein (TNF $\alpha$, IL-6, IL-1 $\beta$, MCP-1, or PAI-1) are reported when significant $(P<0 \cdot 05)$. Data are representative of two or three experiments.

a $10 \mathrm{ng} / \mathrm{ml}$ dose of TNF $\alpha$ caused a $50 \%$ reduction in thymidine incorporation under both basal and IGF-I-stimulated conditions $(P<0 \cdot 001$, Fig. 2), whereas $100 \mathrm{ng} / \mathrm{ml}$ doses of IL-6, IL-1 $\beta$, PAI-1, and MCP-I had no effect.

Next, we characterized the dose-dependent effect of TNF $\alpha$ treatment on proliferation. The MAC-T and pMEC cells were incubated with increasing concentrations of TNF $\alpha(0,0 \cdot 01,0 \cdot 1$, 1 , and $10 \mathrm{ng} / \mathrm{ml}$ ) under basal and IGF-I-stimulated conditions. The minimally effective dose of TNF $\alpha$ in MAC-T cells was $1 \mathrm{ng} / \mathrm{ml}$. This dose reduced basal and IGF-I-mediated thymidine incorporation by $30-35 \%$ (Fig. 3A). In pMEC, the minimally effective concentration was $10 \mathrm{ng} / \mathrm{ml}$ under basal conditions and $1 \mathrm{ng} / \mathrm{ml}$ in the presence of IGF-I (Fig. 3B). These results demonstrate that a low dose of TNF $\alpha$ is sufficient to attenuate IGF-I-stimulated mammary epithelial cell proliferation.

\section{Effects of development and nutrition on MFP production of IRP in prepubertal heifers}

To determine whether the expression of IRP with effects on cell proliferation varies in a manner consistent with diet-induced changes in mammary parenchymal mass, we measured the expression of these factors in the MFP of prepubertal heifers growing at a rate of $650(\mathrm{R})$ or $950 \mathrm{~g} /$ day $(\mathrm{H})$ (Meyer et al. 2006b). The mass of the MFP increased over eightfold in these heifers across the 100-350 kg body weight interval and was $60 \%$ higher in the $\mathrm{H}$ than in the $\mathrm{R}$ heifers at $350 \mathrm{~kg}$ body weight (1126 $\mathrm{g}$ in $\mathrm{H}$ versus $710 \mathrm{~g}$ in $\mathrm{R}$ heifers). The $\mathrm{H}$ heifers also had less DNA per unit of MFP mass than R heifers (Meyer et al. 2006b). TNF $\alpha$ expression in the MFP, however, was unaffected by plane of nutrition or body weight (Fig. 4). We also measured TGF $\beta 1$ expression because it is increased in the serum of rapidly growing heifers and has been shown to inhibit MAC-T and pMEC proliferation (Woodward et al. 1995, Purup et al. $2000 a, b)$. TGF $\beta 1$ expression was not affected by development or nutrition (Fig. 4).
IL-6 and IL-1 $\beta$ expression was not evaluated because these cytokines failed to alter proliferation in vitro. We did, however, measure the expression of MCP-1 and PAI-1 because their activities could depend on factors that were not present in vitro, such as the presence of macrophages for MCP-1 and extracellular matrix proteins for PAI-1 (Lopez-Alemany et al. 2003, Kanda et al. 2006, Tilg \& Moschen 2006). The expression of PAI-1 and MCP-1 was higher in H heifers at $100 \mathrm{~kg}$ of body weight but expression then decreased and remained similar between $\mathrm{R}$ and $\mathrm{H}$ heifers until $350 \mathrm{~kg}$ of body weight. At $350 \mathrm{~kg}$ of body weight, PAI-1 expression was increased over threefold and MCP-1 expression was increased over eightfold in $\mathrm{H}$ compared with $\mathrm{R}$ heifers (Fig. 4). Both plane of nutrition and body weight increased leptin expression (Fig. 4), demonstrating that adipose tissue expansion has positive effects on MFP leptin gene expression, as it does in other adipose depots.

To test the effect of greater MFP expansion in the mammary gland, we analyzed MFP tissue obtained from heifers growing at a rate of $750(\mathrm{R})$ or $1202 \mathrm{~g} /$ day $(\mathrm{H})$ between 42 days of age and slaughter at $240 \mathrm{~kg}$ (Thorn et al. 2006). MFP mass was over three times greater in $\mathrm{H}$ than in $\mathrm{R}$ heifers $(1749 \mathrm{~g}$ in $\mathrm{H}$ versus $474 \mathrm{~g}$ in $\mathrm{R}$ heifers) and leptin expression was increased by threefold, as we previously reported (Thorn et al. 2006). Expression of TNF $\alpha$ and PAI-1 was 50 and 300\% higher in the MFP of $\mathrm{H}$ than in $\mathrm{R}$ heifers, whereas expression of TGF $\beta 1$ and MCP-1 did not differ significantly (Fig. 5).

\section{Discussion}

In rodents, prepubertal expansion of the mammary epithelial compartment proceeds only in the presence of the MFP (Couldrey et al. 2002). This requirement reflects in part the ability of the MFP to synthesize growth factors such as IGF-I, which then drive epithelial cell proliferation (Walden et al. 1998, Kleinberg et al. 2000). Consistent with this model, 
A

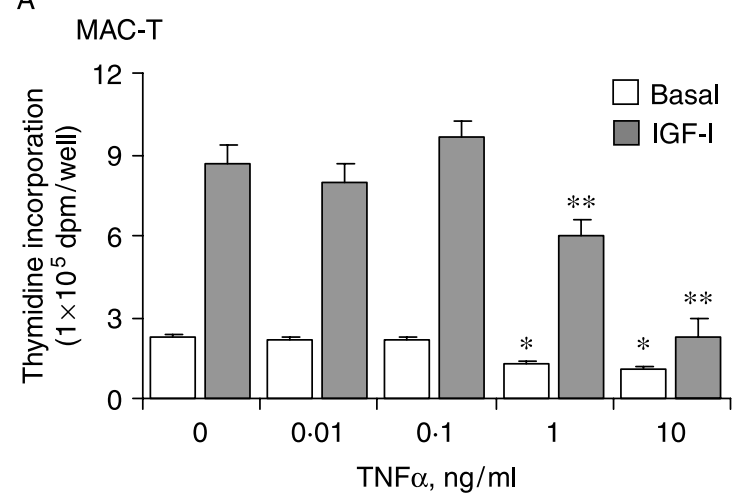

B

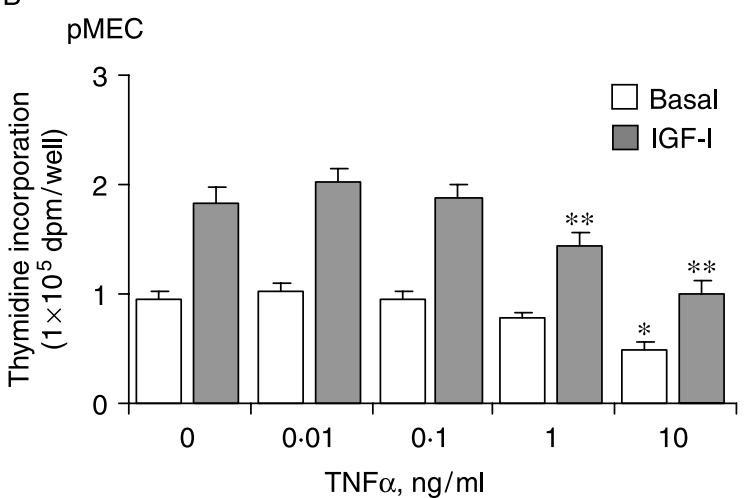

Figure $3 \mathrm{TNF} \alpha$ dose-response in bovine mammary epithelial cells. (A) MAC-T were plated and grown in complete media for $48 \mathrm{~h}$ and then washed and incubated in basal media for $24 \mathrm{~h}$. pMEC were plated and incubated in basal media supplemented with insulin for $24 \mathrm{~h}$. Cells were incubated in basal media supplemented with 0 , $0 \cdot 01,0 \cdot 1,1 \cdot 0$, and $10 \mathrm{ng} / \mathrm{ml}$ of TNF $\alpha$ in the absence of presence of IGF-I $(10 \mathrm{ng} / \mathrm{ml})$. For MAC-T cells, hormone treatments and $\left[{ }^{3} \mathrm{H}\right]$ thymidine were added for $18 \mathrm{~h}$. (B) For pMEC, cells were incubated with hormone treatments for 4 day with a media change every 2 day, and $\left[{ }^{3} \mathrm{H}\right]$ thymidine was added for the last $24 \mathrm{~h}$ of the culture period. Mean \pm S.E.M. is shown for each treatment. Data are representative of two to four experiments. $* P<0 \cdot 05$ compared with cells grown in basal media alone. ${ }^{* *} P<0.05$ compared with cells grown in the presence of IGF-I alone.

prepubertal ductal growth is impaired in IGF-I null mice, but proceeds normally in mice retaining MFP IGF-I production even if deficient in plasma IGF-I (Ruan \& Kleinberg 1999, Richards et al. 2004). Current evidence suggests a similar role for the MFP in prepubertal cattle. IGF-I in the mammary gland is produced in the MFP in response to systemic factors such as estrogen (Berry et al. 2003, Meyer et al. 2006a). Furthermore, the highest density of proliferating epithelial cells is found at the interface with the MFP (Ellis et al. 2000, Capuco et al. 2002). Recent data in rodents and humans have also shown that adipose tissue produces potent inhibitors of IGF-I actions such as TNF $\alpha$, IL-6, and IL-1 $\beta$ and other factors that could modulate IGF-I action such as MCP-1 and PAI-1 (Shen et al. 2002, Lopez-Alemany et al. 2003, Wellen \& Hotamisligil 2005, Sell et al. 2006). TGF $\beta 1$ is also
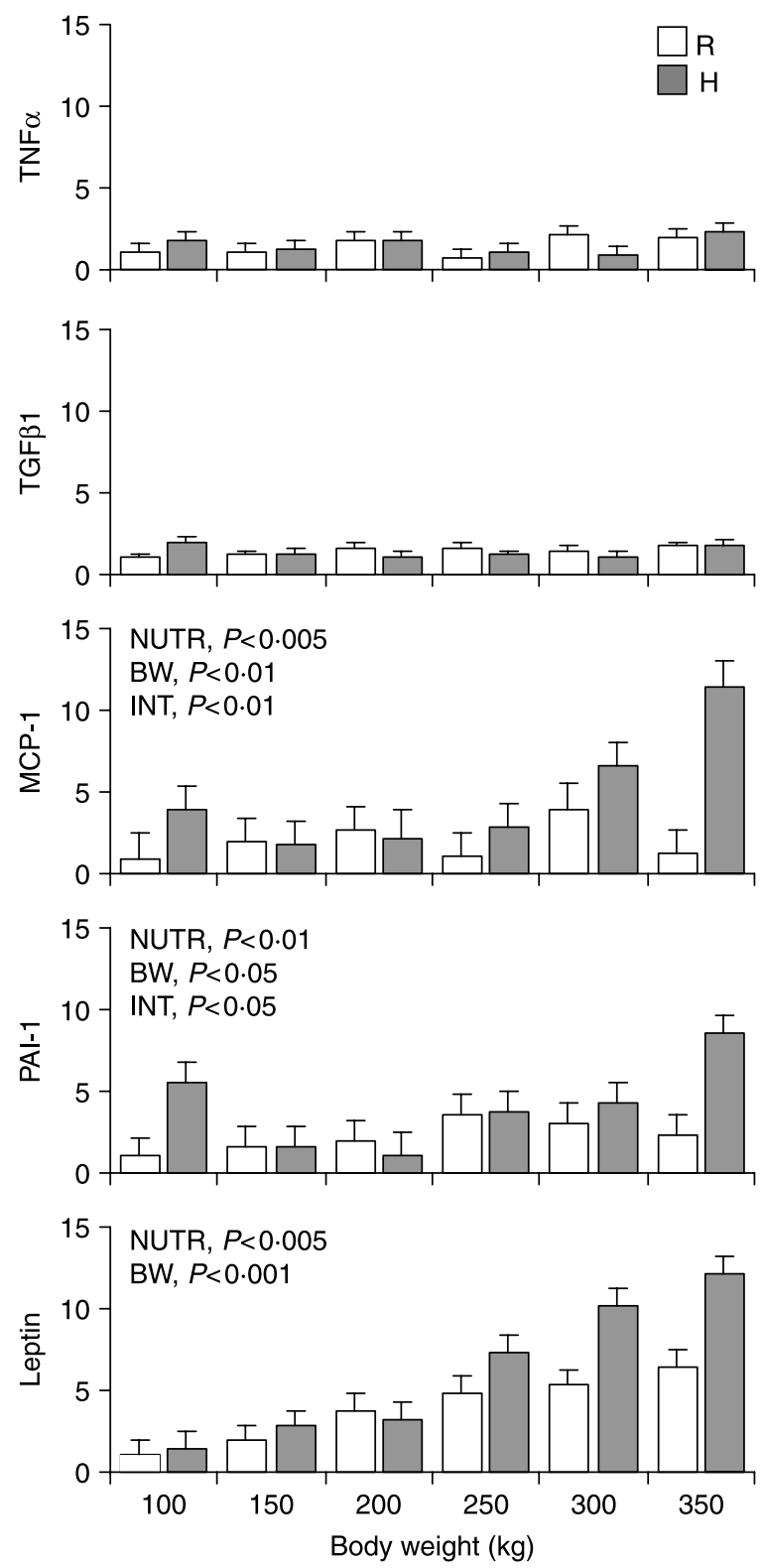

Figure 4 Effect of nutrition and body weight on the mRNA abundance of inflammation-related proteins and leptin in the mammary fat pad of prepubertal dairy heifers. Dairy heifers were offered a restricted $(\mathrm{R})$ or high $(\mathrm{H})$ plane nutrition between 10 days of age and slaughter at $50 \mathrm{~kg}$ intervals from 100 to $350 \mathrm{~kg}$ body weight (six animals per treatment). Total RNA was extracted from the mammary fat pad and analyzed by real-time PCR for the abundance of TNF $\alpha$, TGF $\beta 1$, MCP-1, PAI-1, and leptin. Results are expressed relative to the mean expression level in the MFP of the $100 \mathrm{~kg}$ group on the R plane of nutrition. The effects of nutrition (NUTR), body weight (BW), and their interaction (INT) are reported when significant. Mean \pm S.E.M. is shown for each treatment. 


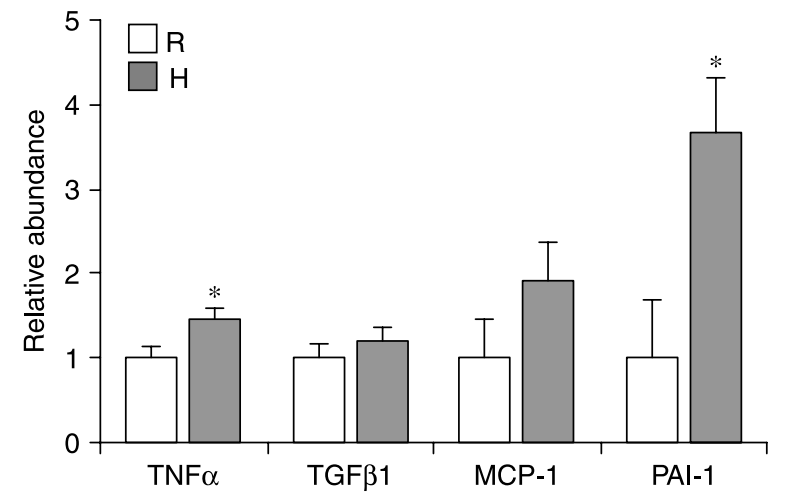

Figure 5 Effect of nutrition on the mRNA abundance of inflammationrelated proteins in the mammary fat pad of prepubertal dairy heifers. Dairy heifers were offered a restricted $(\mathrm{R})$ or high $(\mathrm{H})$ plane nutrition between 42 days of age and slaughter at $240 \mathrm{~kg}$ (12 animals per treatment). Total RNA was extracted from the mammary fat pad and analyzed by real-time PCR for the abundance of TNF $\alpha$, TGF $\beta 1$, $M C P-1$, and PAI-1. Results are expressed relative to the mean expression level in the MFP of the $R$ heifers. Mean \pm S.E.M. is shown for each treatment. ${ }^{*} P<0 \cdot 05$ relative to expression in $\mathrm{R}$ heifers.

expressed in adipose tissue and serum levels are increased in rapidly growing heifers (Purup et al. 2000b). TGF $\beta 1$ has been shown to inhibit bovine mammary epithelial cell proliferation (Woodward et al. 1995, Purup et al. 2000a).

Consistent with the possibility that an IRP could modulate IGF-I-dependent parenchymal growth in dairy heifers, we found that a low dose of TNF $\alpha$ reduced basal and IGF-Istimulated proliferation in both MAC-T and pMEC cells. TNF $\alpha$ has previously been reported to reduce serum-stimulated proliferation in mammary epithelial cells (Okada et al. 1999). Our results suggest that at least a portion of this effect of TNF $\alpha$ is due to the inhibition of IGF-I actions. Our results are also consistent with those showing that TNF $\alpha$ inhibited basal and IGF-I-mediated proliferation in human mammary epithelial cells (Shen et al. 2004). Unlike others, however, we found that high doses of IL- 6 and IL-1 $\beta$ (50 and $100 \mathrm{ng} / \mathrm{ml}$ respectively) did not affect basal or IGF-I-stimulated proliferation of bovine mammary cells. These results are not likely to reflect a lack of activity of human IL- 6 and IL- $1 \beta$ in bovine cells or their use at sub-effective concentrations. Identical or even lower doses of both cytokines elicited other responses in mammary epithelial cells and chondrocytes of bovine origin (Okada et al. 1999, Attur et al. 2000, Andriamanalijaona et al. 2003, Thorn et al. 2006). Similarly, human MCP-1 and PAI-1 are bioactive in rodents and thus likely to react in bovine cells (Sell et al. 2006, Sorrell et al. 2006). Our results indicate that TNF $\alpha$ is unique among the adipose-derived IRP we tested in its ability to inhibit IGF-I-mediated proliferation in vitro in bovine mammary epithelial cells.

In dairy heifers, development and nutrition have been shown to impact indices of mammary parenchymal growth. Specifically, the parenchyma grows allometrically for most of the prepubertal period until heifers reach $\sim 300 \mathrm{~kg}$ of body weight when growth slows to an isometric rate (Meyer et al. 2006c). In the case of nutrition, diets supporting daily growth rates in excess of $700 \mathrm{~g} /$ day are associated with reduced parenchymal mass when assessed in heifers at a similar body weight (Capuco et al. 1995, Sejrsen et al. 2000, Meyer et al. 2006b). Meyer et al. (2006b,c) showed that increased nutrient intake reduced mammary parenchymal mass predominantly by shortening the period of allometric growth. This finding did not exclude the possibility of other negative effects, such as inhibition of IGF-I-mediated cell proliferation by MFP-derived IRP. Indeed, adipose tissue expansion in humans and rodents results in increased production of TNF $\alpha$, IL-6, TGF $\beta 1$, MCP-1, and PAI-1 (Wellen \& Hotamisligil 2005, Tilg \& Moschen 2006). All of these proteins have been shown to reduce insulin or IGF-I actions (Shen et al. 2002, LopezAlemany et al. 2003, Sartipy \& Loskutoff 2003, Sell et al. 2006). This may explain why indices of mammary parenchymal growth are reduced with development and increased nutrient intake, even though the MFP IGF-I expression is unchanged when these reductions are detected (Meyer et al. 2007). Our in vivo data, however, offer little support for such a mechanism. Specifically, neither TNF $\alpha$ nor TGF $\beta 1$ expression was affected by development or nutrition in the first experiment. Increased nutrient intake did increase MCP-1 and PAI-1 expression, but in a manner that is inconsistent with the hypothesis. The $\mathrm{H}$ heifers had increased expression of MCP-1 and PAI-I at $100 \mathrm{~kg}$ body weight in the absence of MFP expansion and in conjunction with a higher rate of epithelial cell proliferation than $\mathrm{R}$ heifers, and again at $350 \mathrm{~kg}$ body weight when epithelial cell proliferation was unaffected by nutrient intake (Meyer et al. 2006b,c). Moreover, MCP-1 and PAI-I expression did not increase at $300 \mathrm{~kg}$ body weight when allometric growth ceased (Meyer et al. 2006c). Significant increases in TNF $\alpha$ and PAI-1, but not TGF $\beta 1$ or MCP-1, were observed in the second experiment, where the MFP had a greater degree of expansion in response to increased nutrient intake. Overall, these data show that MFP expansion does increase the production of IRP in dairy cattle, but give little support to the idea that these factors contribute to the reduced parenchymal growth observed with development or increased nutrient intake.

It is interesting to compare these results with those obtained with leptin, another cytokine hypothesized to mediate the negative effects of the expanding MFP on mammary parenchymal growth (Silva et al. 2002). Leptin expression in the MFP increases with development and nutrient intake. Quantitative real-time PCR assays have shown that the signaling form of the leptin receptor $(\mathrm{Ob}-\mathrm{Rb})$ is undetectable in MAC-T and pMEC cells and negligible in mammary parenchyma when compared with the hypothalamus, a recognized leptin target tissue (Thorn et al. 2006, 2007). Moreover, leptin is unable to induce signaling events or alter basal and IGF-I-stimulated proliferation in cultured bovine mammary epithelial cells (Thorn et al. 2006). Thus, despite an expression profile in the MFP that is consistent with modulation of parenchymal growth, leptin is unable to do so by acting directly on epithelial cells. In contrast, TNF $\alpha$ and TGF $\beta 1$ are potent inhibitors of IGF-Imediated proliferation in vitro, but are unlikely to explain 
reduced parenchymal growth because neither development nor nutrition consistently altered their expression in the MFP.

In conclusion, TNF $\alpha$ has potent inhibitory effects on mammary epithelial cell proliferation in vitro. MFP expression of TNF $\alpha$, TGF $\beta 1$, MCP-1, and PAI-1 was static around the time when allometric parenchymal growth ceases. Moreover, increased nutrient intake reduced mammary parenchymal mass in both the absence and the presence of increased TNF $\alpha$ and PAI-1 expressions. Overall, these data suggest that MFP production of IRP is unlikely to play a role in terminating the allometric growth phase of the mammary parenchyma or in reducing parenchymal mass in heifers fed high planes of nutrition.

\section{Acknowledgements}

This work was supported by the Cornell University Agricultural Experimental Station. The authors thank A Kamgaard Nielsen and K Bøgild Poulsen for their skilled technical assistance. The authors declare that there is no conflict of interest that would prejudice the impartiality of this scientific work.

\section{References}

Andriamanalijaona R, Felisaz N, Kim SJ, King-Jones K, Lehmann M, Pujol JP \& Boumediene K 2003 Mediation of interleukin-1beta-induced transforming growth factor beta1 expression by activator protein 4 transcription factor in primary cultures of bovine articular chondrocytes: possible cooperation with activator protein 1. Arthritis and Rheumatism 48 1569-1581.

Attur MG, Dave M, Cipolletta C, Kang P, Goldring MB, Patel IR, Abramson SB \& Amin AR 2000 Reversal of autocrine and paracrine effects of interleukin 1 (IL-1) in human arthritis by type II IL-1 decoy receptor. Potential for pharmacological intervention. Journal of Biological Chemistry 275 40307-40315.

Berry SD, Howard RD, Jobst PM, Jiang H \& Akers RM 2003 Interactions between the ovary and the local IGF-I axis modulate mammary development in prepubertal heifers. Journal of Endocrinology 177 295-304.

Capuco AV, Smith JJ, Waldo DR \& Rexroad CE Jr 1995 Influence of prepubertal dietary regimen on mammary growth of Holstein heifers. Journal of Dairy Science 78 2709-2725.

Capuco AV, Ellis S, Wood DL, Akers RM \& Garrett W 2002 Postnatal mammary ductal growth: three-dimensional imaging of cell proliferation, effects of estrogen treatment, and expression of steroid receptors in prepubertal calves. Tissue Cell 34 143-154.

Chen A, Mumick S, Zhang C, Lamb J, Dai H, Weingarth D, Mudgett J, Chen H, MacNeil DJ, Reitman ML et al. 2005 Diet induction of monocyte chemoattractant protein-1 and its impact on obesity. Obesity Research $\mathbf{1 3}$ $1311-1320$.

Connor EE, Meyer MJ, Li RW, Van Amburgh ME, Boisclair YR \& Capuco AV 2007 Regulation of gene expression in the bovine mammary gland by ovarian steroids. Journal of Dairy Science 90 (Suppl 1) E55-E65.

Couldrey C, Moitra J, Vinson C, Anver M, Nagashima K \& Green J 2002 Adipose tissue: a vital in vivo role in mammary gland development but not differentiation. Developmental Dynamics 223 459-468.

Czekay RP, Aertgeerts K, Curriden SA \& Loskutoff DJ 2003 Plasminogen activator inhibitor-1 detaches cells from extracellular matrices by inactivating integrins. Journal of Cell Biology 160 781-791.
Ellis S, Purup S, Sejrsen K \& Akers RM 2000 Growth and morphogenesis of epithelial cell organoids from peripheral and medial mammary parenchyma of prepubertal heifers. Journal of Dairy Science 83 952-961.

Huynh HT, Robitaille G \& Turner JD 1991 Establishment of bovine mammary epithelial cells (MAC-T): an in vitro model for bovine lactation. Experimental Cell Research 197 191-199.

Kanda H, Tateya S, Tamori Y, Kotani K, Hiasa K, Kitazawa R, Kitazawa S, Miyachi H, Maeda S, Egashira K et al. 2006 MCP-1 contributes to macrophage infiltration into adipose tissue, insulin resistance, and hepatic steatosis in obesity. Journal of Clinical Investigation 116 1494-1505.

Kleinberg DL, Feldman M \& Ruan W 2000 IGF-I: an essential factor in terminal end bud formation and ductal morphogenesis. Journal of Mammary Gland Biology and Neoplasia 5 7-17.

Kortlever RM, Higgins PJ \& Bernards R 2006 Plasminogen activator inhibitor-1 is a critical downstream target of $\mathrm{p} 53$ in the induction of replicative senescence. Nature Cell Biology 8 877-884.

Lopez-Alemany R, Redondo JM, Nagamine Y \& Munoz-Canoves P 2003 Plasminogen activator inhibitor type- 1 inhibits insulin signaling by competing with alphavbeta 3 integrin for vitronectin binding. European Journal of Biochemistry 270 814-821.

Maile LA, Busby WH, Sitko K, Capps BE, Sergent T, Badley-Clarke J, Ling Y \& Clemmons DR 2006 The heparin binding domain of vitronectin is the region that is required to enhance insulin-like growth factor-I signaling. Molecular Endocrinology 20 881-892.

Meyer MJ, Capuco AV, Boisclair YR \& Van Amburgh ME 2006a Estrogendependent responses of the mammary fat pad in prepubertal dairy heifers. Journal of Endocrinology 190 819-827.

Meyer MJ, Capuco AV, Ross DA, Lintault LM \& Van Amburgh ME $2006 b$ Developmental and nutritional regulation of the prepubertal heifer mammary gland: I parenchyma and fat pad mass and composition. Journal of Dairy Science 89 4289-4297.

Meyer MJ, Capuco AV, Ross DA, Lintault LM \& Van Amburgh ME 2006c Developmental and nutritional regulation of the prepubertal bovine mammary gland: II epithelial cell proliferation, parenchymal accretion rate, and allometric growth. Journal of Dairy Science 89 4298-4304.

Meyer MJ, Rhoads RP, Capuco AV, Connor EE, Hummel A, Boisclair YR \& Van Amburgh ME 2007 Ontogenic and nutritional regulation of steroid receptor and IGF-I transcript abundance in the prepubertal heifer mammary gland. Journal of Endocrinology 195 59-66.

Okada H, Miyake Y, Ohtsuka H, Kiku Y, Fukuda S, Watanabe A, Yokomizo Y, Rosol TJ \& Yoshino T 1999 Effects of isoprothiolane on cell growth of cultured bovine mammary epithelial cells. Journal of Veterinary Medical Science 61 553-556.

Purup S, Vestergaard M \& Sejrsen K 2000a Involvement of growth factors in the regulation of pubertal mammary growth in cattle. Advances in Experimental Medicine and Biology 480 27-43.

Purup S, Vestergaard M, Weber MS, Plaut K, Akers RM \& Sejrsen K $2000 b$ Local regulation of pubertal mammary growth in heifers. Journal of Animal Science 78 (Suppl 3) 36-47.

Purup S, Jensen SK \& Sejrsen K 2001 Differential effects of retinoids on proliferation of bovine mammary epithelial cells in collagen gel culture. Journal of Dairy Science 68 157-164.

Richards RG, Klotz DM, Walker MP \& Diaugustine RP 2004 Mammary gland branching morphogenesis is diminished in mice with a deficiency of insulin-like growth factor-I (IGF-I), but not in mice with a liver-specific deletion of IGF-I. Endocrinology 145 3106-3110.

Ruan W \& Kleinberg DL 1999 Insulin-like growth factor I is essential for terminal end bud formation and ductal morphogenesis during mammary development. Endocrinology 140 5075-5081.

Rui L, Yuan M, Frantz D, Shoelson S \& White MF 2002 SOCS-1 and SOCS-3 block insulin signaling by ubiquitin-mediated degradation of IRS1 and IRS2. Journal of Biological Chemistry 277 42394-42398.

Sartipy P \& Loskutoff DJ 2003 Monocyte chemoattractant protein 1 in obesity and insulin resistance. PNAS 100 7265-7270.

Sejrsen K, Huber JT, Tucker HA \& Akers RM 1982 Influence of nutrition of mammary development in pre- and postpubertal heifers. Journal of Dairy Science 65 793-800. 
Sejrsen K, Purup S, Vestergaard M \& Foldager J 2000 High body weight gain and reduced bovine mammary growth: physiological basis and implications for milk yield potential. Domestic Animal Endocrinology 19 93-104.

Sell H, Dietze-Schroeder D, Kaiser U \& Eckel J 2006 Monocyte chemotactic protein-1 is a potential player in the negative cross-talk between adipose tissue and skeletal muscle. Endocrinology 147 2458-2467.

Shen WH, Zhou JH, Broussard SR, Freund GG, Dantzer R \& Kelley KW 2002 Proinflammatory cytokines block growth of breast cancer cells by impairing signals from a growth factor receptor. Cancer Research 62 4746-4756.

Shen WH, Yin Y, Broussard SR, McCusker RH, Freund GG, Dantzer R \& Kelley KW 2004 Tumor necrosis factor alpha inhibits cyclin A expression and retinoblastoma hyperphosphorylation triggered by insulin-like growth factor-I induction of new E2F-1 synthesis. Journal of Biological Chemistry 279 7438-7446.

Shoelson SE, Lee J \& Goldfine AB 2006 Inflammation and insulin resistance. Journal of Clinical Investigation 116 1793-1801.

Silva LF, VandeHaar MJ, Weber Nielsen MS \& Smith GW 2002 Evidence for a local effect of leptin in bovine mammary gland. Journal of Dairy Science $\mathbf{8 5}$ 3277-3286

Sorrell AM, Shand JH, Tonner E, Gamberoni M, Accorsi PA, Beattie J, Allan GJ \& Flint DJ 2006 Insulin-like growth factor-binding protein-5 activates plasminogen by interaction with tissue plasminogen activator, independently of its ability to bind to plasminogen activator inhibitor-1, insulin-like growth factor-I, or heparin. Journal of Biological Chemistry 281 10883-10889.

Stefansson S \& Lawrence DA 1996 The serpin PAI-1 inhibits cell migration by blocking integrin alpha V beta 3 binding to vitronectin. Nature 383 441-443.

Thorn SR, Purup S, Cohick WS, Vestergaard M, Sejrsen K \& Boisclair YR 2006 Leptin does not act directly on mammary epithelial cells in prepubertal dairy heifers. Journal of Dairy Science 89 1467-1477.
Thorn SR, Meyer MJ, Van Amburgh ME \& Boisclair YR 2007 Effect of estrogen on leptin and expression of leptin receptor transcripts in prepubertal dairy heifers. Journal of Dairy Science 90 3742-3750.

Tilg H \& Moschen AR 2006 Adipocytokines: mediators linking adipose tissue, inflammation and immunity. Nature Reviews, Immunology 6 772-783.

Walden PD, Ruan W, Feldman M \& Kleinberg DL 1998 Evidence that the mammary fat pad mediates the action of growth hormone in mammary gland development. Endocrinology 139 659-662.

Weber MS, Purup S, Vestergaard M, Ellis SE, Scndergard-Andersen J, Akers RM \& Sejrsen K 1999 Contribution of insulin-like growth factor (IGF)-I and IGFbinding protein-3 to mitogenic activity in bovine mammary extracts and serum. Journal of Endocrinology 161 365-373.

Wellen KE \& Hotamisligil GS 2005 Inflammation, stress, and diabetes. Journal of Clinical Investigation 115 1111-1119.

Woodward TL, Dumont N, O'Connor-McCourt M, Turner JD \& Philip A 1995 Characterization of transforming growth factor-beta growth regulatory effects and receptors on bovine mammary cells. Journal of Cellular Physiology 165 339-348.

Received in final form 18 November 2007

Accepted 4 December 2007

Made available online as an Accepted Preprint 4 December 2007 